International Journal of Economics, Business and Accounting Research (IJEBAR)

Peer Reviewed - International Journal

Vol-4, Issue-2, 2020 (IJEBAR)

E-ISSN: 2614-1280 P-ISSN 2622-4771

https://jurnal.stie-aas.ac.id/index.php/IJEBAR

\title{
BUSINESS TRAINING DEVELOPMENT MODEL THROUGH PROJECT BASED LEARNING ON STUDENTS
}

\author{
Indra Hastuti 1 Indah Wahyu Utami2 \\ 1Information System Study Program, 2 Informatics Engineering Study Program \\ Universitas Duta Bangsa Surakarta \\ Email:indra_hastuti@udb.ac.id, indah_wahyu@udb.ac.id
}

\begin{abstract}
This research was conducted aiming to find a model of developing entrepreneurship training through a Project Based Learning approach based on contextual business problems, applying planned businesses in real terms. This model is expected to be a form of community-based education (fostering active participation of students in education and training) that is able to form new entrepreneurs to benefit, create jobs to reduce unemployment and poverty in Indonesia. This study uses qualitative research methods with a simulation observation research strategy. Observations were made on student business pilot groups, each group consisting of 4-5 students taking the Entrepreneurship course. The results obtained by the development model of entrepreneurship training in students. From the results of the entrepreneurship mapping, students can plan businesses according to their interests and expertise and through the training development model students can solve problems in business plans related to leadership, courage in taking risks, perseverance to focus on doing work, the level of discipline so students can successfully build businesses new business.
\end{abstract}

Keywords: $\quad$ Model, training, business plan, entrepreneurship

\section{Introduction}

College students in Indonesia after graduating the majority are looking for work and they are happy to work for others. Only a few students after graduation become job creators, this results in the low number of young entrepreneurs who emerge so that there is a need to grow interest in becoming entrepreneurs in students. According to Purnomo (2014), student interest in entrepreneurship is influenced, among others, by the family environment, education and social environment. Developing individuals to be successful can be achieved by projects that can be carried out by entrepreneurship training students. Lies, Indriyatni at all, (2015)

Entrepreneurship or entrepreneurship is a creative business that is built on innovation to produce something new, have added value, provide benefits, create jobs and the results are useful for others, Jaharuddin, Purnawan, etc, (2017). Entrepreneurship can be interpreted as the ability of individuals to create economic opportunities from a business idea both small and large scale. Individual abilities related to the potential possessed by each individual. Therefore, before starting to become an entrepreneur, knowing yourself is very important to know about your competencies, talents, interests and hobbies. By knowing what potential or interest they have, it will be easier for us to determine what type of business we want to build. The development of science and technology opens various business and entrepreneurship business opportunities, Sulastri Ayu, (2016) The existence and growth of entrepreneurs is very necessary for the economic development of a country. Business development from year to year is increasing rapidly. The development of the business facilitates work and also changes lifestyles. 
International Journal of Economics, Business and Accounting Research (IJEBAR)

Peer Reviewed - International Journal

Vol-4, Issue-2, 2020 (IJEBAR)

E-ISSN: 2614-1280 P-ISSN 2622-4771

https://jurnal.stie-aas.ac.id/index.php/IJEBAR

Business development also gave rise to new entrepreneurs in various fields including the fields of technopreneurship, agropreneurship, edupreneurship, creative entrepreneurship, digital tehnopreneurship, MSME entrepreneurship. MSME (Micro, Small and Medium Enterprises), in its implementation MSMEs apply the principles of togetherness, a democratic economy, independence, balance of progress, sustainability, efficiency of justice, and national economic unity. MSMEs have a stake in national economic development and have a stake in employment. MSMEs will not take effect when a crisis occurs. After the economic crisis that was experienced by Indonesia in 1997-1998, MSMEs persisted and supported the country's economy. SMEs play a role in the ASEAN economy, currently $96 \%$ of ASEAN companies are SMEs. Until now, several Indonesian MSMEs have been able to penetrate the global market (Go.UKM, 2017). According to BPS data (2014), the number of MSMEs in Indonesia has 57.89 million units or 99.99 percent of the total number of national businesses. Based on the Ministry of Cooperatives and SME Data, the number of entrepreneurs in Indonesia also jumped from 0.24 percent to 1, 56 percent of the population. Even so the number is still far from the target of Indonesian entrepreneurs who should ideally be at least 2 percent of the population. The number of entrepreneurs and entrepreneurs in a country affects the economic condition of the country itself.

Important aspects in business development and entrepreneurship related to technopreneurship, digital technopreneurship, edupreneurship, creative entrepreneurship, agropreneurship are infrastructure and Human Resources (HR), Purnomo, Lestari, Hastuti (2016). Increasing the ability of innovation and student creativity in building an entrepreneur must be adjusted by his ability and the support of existing stakeholders. Purnomo, Lestari, Hastuti (2017). Universities have an indirect obligation to create an entrepreneur. This is in accordance with the 3 pillars of higher education namely education, research, and community service. To realize this, an appropriate model of entrepreneurship training development is needed so that the organization of entrepreneurship education and training is successful in growing new and developing entrepreneurs and students do not just stop at completion.

\section{Research Methodology}

This research was conducted using qualitative methods with an observation simulation strategy. In this study the subjects of this study were given direction so that they would carry out activities with Project Based Learning. Directives are given to the subject verbally and in writing. The observations were made on groups, where each group consisted of 4-5 students. This research is a type of research using a class action approach. The location of this research was conducted at Duta Bangsa Surakarta University for the Informatics Engineering study program.

This research was conducted in the even semester of the academic year 2018/1019. The research subjects were students at the University of Duta Bangsa Surakarta who took entrepreneurship courses with a sample of 100 research subjects. The research variable contains the character of entrepreneurship which is quoted from several literatures consisting of several variables, namely: able to lead, take risks, persevere, focus, discipline, Lies, Indriyati (2017) Data sources used are primary data and secondary data. While the method of collecting data through questionnaires, interviews, documentation, and observation. 
International Journal of Economics, Business and Accounting Research (IJEBAR)

Peer Reviewed - International Journal

Vol-4, Issue-2, 2020 (IJEBAR)

E-ISSN: 2614-1280 P-ISSN 2622-4771

https://jurnal.stie-aas.ac.id/index.php/IJEBAR

Research Flow Diagram, described as follows:

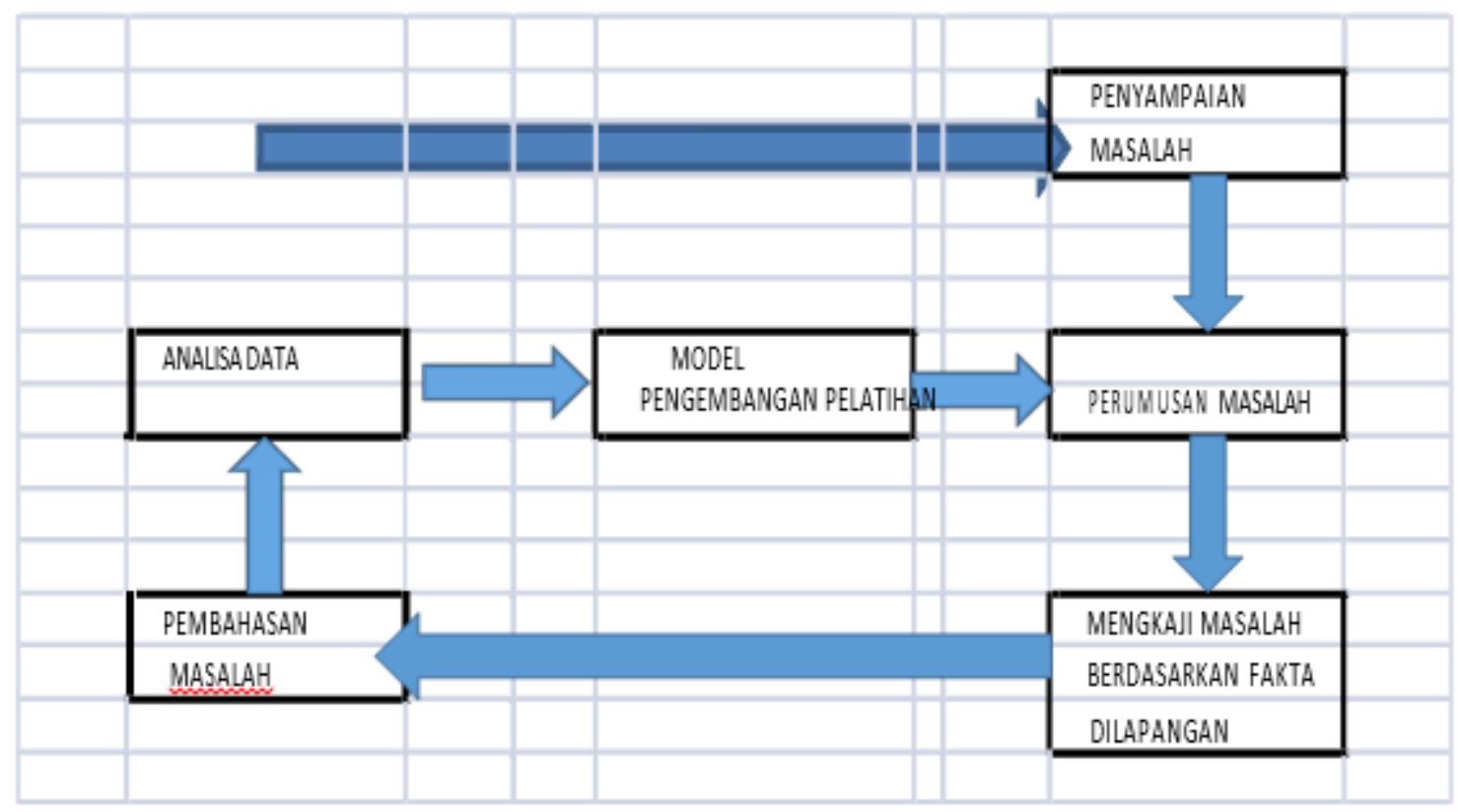

Figure 3. Research Flow Diagram

\section{Results and Discussion}

The results of research and data analysis were performed using quantitative descriptive analysis. The learning model used as research material is a project-based learning model. From the results of the study there are several actions used to develop the model, namely:

a. Designing the implementation of entrepreneurial learning in the form of Semester learning plans (RPS)

b. Carrying out the Project Based learning process in developing and applying an entrepreneurial spirit including:

1) Create groups in classes between 4-5 people

2) Gather information: carry out the learning process by providing basic material, concise discussions and views of the projects implemented.

3) Give field assignments from the material provided and make project activities from the learning process carried out.

4) Consultation of the progress of the activities carried out and assess the progress of the task or project.

5) Carry out activities / present project results, conduct assessments and provide feedback.

c. Conduct an evaluation of projects that have been implemented. Based on the results of research instruments in the form of observation sheets of student entrepreneurial character through projectbased learning.

Variables able to lead, take risks, persevere, focus, discipline are used to assess the character of students. The data collected was analyzed descriptively. The creativity observation data collected was in the form of an assessment with a maximum score of 10 . The score was analyzed as a percentage, using the formula: 
International Journal of Economics, Business and Accounting Research (IJEBAR)

Peer Reviewed - International Journal

Vol-4, Issue-2, 2020 (IJEBAR)

E-ISSN: 2614-1280 P-ISSN 2622-4771

https://jurnal.stie-aas.ac.id/index.php/IJEBAR

$\mathrm{NP}=\mathrm{R} / \mathrm{SM} \times 100$

NP Description: Percent value

R: Raw scores obtained

SM: Ideal maximum score

The next step is to interpret the quantitative data to the qualitative data. The interpretation technique is as follows. 76\%-100\%: Good. 56\%-75\%: Good Enough. 40\% -55\%: Not Good. <40\%: Not good. From the observation results obtained a score of $81.5 \%$ (Good).

In the Project Based Learning (PBL) method, it involves students as real objects in the learning process. The physical, mind and mental involvement of these students will be able to encourage motivation to learn, decision-making skills, and practice critical thinking and innovative work in solving various business problems encountered. At the beginning of the learning process activities certain problems were conveyed to students. Then, in small groups, the problem must be examined carefully. Furthermore, students make observations in the field and look for sources of reference. Students as objects then conduct discussions in their groups with the help of the accompanying lecturer, so they can find explanations, solutions or group recommendations for the problems they are learning. The group's findings are then disseminated in class to get input, suggestions and assessments from other groups and entrepreneurship mentoring lecturers.

\section{Conclusion}

Project-based learning model (Project Based Learning) for students is suitable to be applied in learning entrepreneurship courses in universities or higher education. The physical, mind and mental involvement of these students is able to encourage learning motivation, decision-making skills, and practice critical thinking and innovative work in solving various business start-up problems faced. The entrepreneurial spirit will be formed through creative and innovative mindset, discipline, hard work, high enthusiasm in entrepreneurship and social life in the community.

\section{Acknowledgments}

Our gratitude goes to the Chancellor of Duta Bangsa Surakarta University for giving us the opportunity to conduct research on Duta Bangsa Surakarta University Students, Duta Bangsa Surakarta University who have provided funding to fund this research, Head of LPPM Duta Bangsa University and Secretary of LPPM Duta University Surakarta nation has provided direction and guidance on conducting research.

\section{References}

Balai Pusat Statistik (BPS), (2014)

Jaharuddin, Purnawan, etc, 2017, Strategi Melahirkan Mahasiswa Pengusaha Pemula (Studi Kasus Mahasiswa Universitas Muhammadiyah Jakarta), Jurnal Kewirausahaan \& Bisnis ISSN : 1979-861X E-ISSN : 2549-1555

Keputusan Menteri Koperasi dan Pembinaan Pengusaha Kecil, Nomor 961/KEP/M/XI/1995.

Kompas. 1 Januari 2013. Industri Kreatif dan Kategorinya di Indonesia. (ONLINE) http:// creatips.net/2013/01/industri-kreatif-dan-kat- egorinya- diindonesial 
International Journal of Economics, Business and Accounting Research (IJEBAR)

Peer Reviewed - International Journal

Vol-4, Issue-2, 2020 (IJEBAR)

E-ISSN: 2614-1280 P-ISSN 2622-4771

https://jurnal.stie-aas.ac.id/index.php/IJEBAR

Lies Indriyatni at all, 2015, Pengembangan Model Pelatihan Kewirausahaan untuk Perempuan Pengangguran di Kabupaten Demak, Jurusan Akuntansi STIE Pelita Nusantara

Purnomo, Lestari ,Hastuti.,2016 Aplikasi Komputasi Cerdas Sebagai Konsultan Bisnis Dan Technopreneurship Bidang Teknologi Informasi Untuk Mahasiswa, tahun ke 1 dari rencana 2 tahun . Penelitian Hibah Bersaing Kemenristek Dikti

Purnomo,Lestari,Hastuti, 2017. Expert System Design For Guidance of Information Technologi Technopreneurships Based on Students Personal Characteristics, Internasional Journal of Enginering Reseach \& Technology (IJERT), ISSN : 2278-0181, vol.6, Issue 11, November-2017, Publised by : http://www.ijert.org

Purnomo,S., 2014, Analisis Pengaruh Keluarga, Pendidikan dan Lingkunagn Terhadap Minat berwirausaha Mahasiswa STMIK Duta Bangsa Surakarta, Jurnal Saintech, Vol. 1 No. 1, ISSN : 2355-5009.

Rifiani Ita P, Sulasari Ayu, Romlah Siti; 2013; Integrated Entrepreneurship pogram: Membentuk Kepedulian Mahasiswa terhadap Industri Kreatif ; Jurnal Senapati; Bali

Sulastri Ayu, 2016 Pengembangan Metode Pembelajaran Kewirausahaan Berbasis Proyek Untuk meningkatkan Karakter Wirausaha Mahasiswa di Politeknik Negeri Malang. Politeknik Negeri Malang, J1. Soekarno Hatta No.9 Malang 